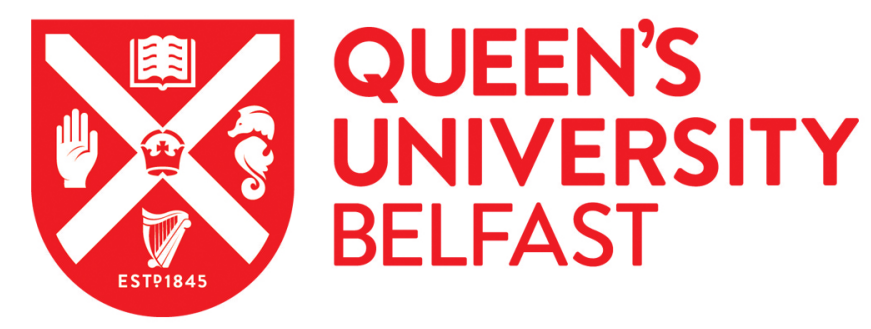

\title{
The value of adjuvant radiotherapy on survival and recurrence in triple-negative breast cancer: a systematic review and meta-analysis of 5,507 patients
}

O'Rorke, M. A., Murray, L. J., Brand, J. S., \& Bhoopathy, N. (2016). The value of adjuvant radiotherapy on survival and recurrence in triple-negative breast cancer: a systematic review and meta-analysis of 5,507 patients. Cancer treatment reviews, 47, 12-21. https://doi.org/10.1016/j.ctrv.2016.05.001

\section{Published in:}

Cancer treatment reviews

\section{Document Version:}

Peer reviewed version

Queen's University Belfast - Research Portal:

Link to publication record in Queen's University Belfast Research Portal

\section{Publisher rights}

Copyright 2016 Elsevier.

This manuscript is distributed under a Creative Commons Attribution-NonCommercial-NoDerivs License

(https://creativecommons.org/licenses/by-nc-nd/4.0/), which permits distribution and reproduction for non-commercial purposes, provided the author and source are cited.

\section{General rights}

Copyright for the publications made accessible via the Queen's University Belfast Research Portal is retained by the author(s) and / or other copyright owners and it is a condition of accessing these publications that users recognise and abide by the legal requirements associated with these rights.

\section{Take down policy}

The Research Portal is Queen's institutional repository that provides access to Queen's research output. Every effort has been made to ensure that content in the Research Portal does not infringe any person's rights, or applicable UK laws. If you discover content in the Research Portal that you believe breaches copyright or violates any law, please contact openaccess@qub.ac.uk. 
Title: The value of adjuvant radiotherapy on survival and recurrence in triplenegative breast cancer: a systematic review and meta-analysis of 5,507 patients. Authors: O'Rorke MA ${ }^{1 *}$, Murray $\mathrm{LJ}^{1}$, Brand $\mathrm{J}^{2}$, Bhoo-Pathy $\mathrm{N}^{3}$

\section{Affiliations:}

${ }^{1}$ Centre for Public Health, Queen's University Belfast, Royal Victoria Hospital Site, Grosvenor Road, Belfast, BT12 6BJ

${ }^{2}$ Department of Medical Epidemiology and Biostatistics, Karolinska Institutet, Nobels väg 12A 17177 Stockholm, Sweden.

${ }^{3}$ Julius Centre University of Malaya (JCUM), Faculty of Medicine, University of Malaya, 50603 Lembah Pantai, Kuala Lumpur, Malaysia.

${ }^{*}$ Corresponding author:

Michael O'Rorke, Centre for Public Health, Queen's University Belfast, Royal Victoria Hospital Site, Grosvenor Road, Belfast, BT12 6BJ

Email: m.ororke@qub.ac.uk | Tel: +44 (0)28 90978997 
Title: The value of adjuvant radiotherapy on survival and recurrence in triplenegative breast cancer: a systematic review and meta-analysis of 5,507 patients. 


\section{ABSTRACT:}

BACKGROUND: The value of adjuvant radiotherapy in triple negative breast cancer (TNBC) remains unclear. A systematic review and meta-analysis was conducted in TNBC patients to assess survival and recurrence outcomes associated with radiotherapy following either breast conserving therapy (BCT) or post-mastectomy radiotherapy (PMRT).

METHODS: Four electronic databases were searched from January 2000 to November 2015 (PubMed, MEDLINE, EMBASE and Web of Science). Studies investigating overall survival and/or recurrence in TNBC patients according to radiotherapy administration were included. A random effects meta-analysis was conducted using mastectomy only patients as the reference.

RESULTS: Twelve studies were included. The pooled hazard ratio (HR) for locoregional recurrence comparing BCT and PMRT to mastectomy only was 0.61 (95\% confidence interval [Cl] 0.41-0.90) and 0.62 (95\% Cl 0.44-0.86), respectively. Adjuvant radiotherapy was not significantly associated with distant recurrence. The pooled HR for overall survival comparing BCT and PMRT to mastectomy only was $0.57(95 \% \mathrm{Cl} 0.36-0.88)$ and $\mathrm{HR} 1.12(95 \% \mathrm{Cl} 0.75,1.69)$. Comparing PMRT to mastectomy only, tests for interaction were not significant for stage $(p=0.98)$ or age at diagnosis $(p=0.85)$. However, overall survival was improved in patients with latestage disease (T3-4, N2-3) pooled HR 0.53 (95\% Cl 0.32-0.86), and women <40 years, pooled HR 0.30 (95\% Cl 0.11-0.82).

CONCLUSIONS: Adjuvant radiotherapy was associated with a significantly lower risk of locoregional recurrence in TNBC patients, irrespective of the type of surgery. While radiotherapy was not consistently associated with an overall survival gain, benefits may be obtained in women with late-stage disease and younger patients. 
Keywords: Triple negative breast cancer, radiotherapy, surgery, meta-analysis, survival, recurrence. 


\section{INTRODUCTION:}

Triple negative breast cancer (TNBC) accounts for $10-15 \%$ of all breast cancer [1] and is defined by an immunohistochemical absence of expression for oestrogen receptor (ER), progesterone receptor (PR) and human epidermal growth factor receptor 2 (HER2) [2]. Patients with TNBC typically present with high-grade disease and often an early pattern of recurrence $[1,3-5]$. With no drug-targetable receptors [6], chemotherapy continues to be the mainstay of treatment in TNBC patients.

At present, there are no specific clinical guidelines for treating TNBC $[7,8]$. Like other breast cancers, locoregional management of TNBC comprises breast conserving therapy (BCT) i.e.: breast conserving surgery followed by radiotherapy, or mastectomy (with or without adjuvant radiotherapy). While there is international consensus on indications for postmastectomy radiotherapy (PMRT) [8-10], these guidelines do not account for breast cancer subtype.

A recent systematic review of over 12,000 patients by Lowery et al [11] examined locoregional recurrence risk after breast cancer surgery according to receptor phenotype. The authors compared TNBC patients to other non-TNBC patients and found that TNBC was associated with an increased risk of locoregional recurrence following BCT, as well as mastectomy. The findings of this study are important, as it serves to highlight that TNBC is an aggressive disease with a higher risk of local recurrence compared to other breast cancer subtypes, irrespective of the locoregional therapy. Nevertheless, this systematic review does not provide evidence on whether the surgical procedures per se, or adjuvant radiotherapy therein, have any prognostic role in TNBC. In order to address the ongoing debate of 
whether adjuvant radiotherapy confers any recurrence-free or survival benefit in patients with TNBC [12-16], there needs to be a direct comparison between various locoregional treatment strategies within patients with triple negative disease.

Previous studies examining recurrence and survival outcomes in patients with TNBC according to locoregional treatment status have produced conflicting results [17-29]. It is likely that several of these studies were underpowered due to their small sample size $[19-21,30]$. Moreover, potentially important survival differences may exist depending on disease stage $[18,22]$ and age at diagnosis [18]. We therefore conducted a meta-analysis to determine the risk of locoregional/distant recurrence, and overall survival associated with BCT or PMRT, versus mastectomy alone in patients with TNBC. Such analysis is needed for informed decision-making regarding the optimum locoregional treatment strategies in TNBCs. 


\section{METHODOLOGY:}

\section{Search strategy}

This meta-analysis was conducted in accordance to the preferred reporting items for systematic reviews and meta-analyses (PRISMA) statement [31]. Four electronic databases (MEDLINE, EMBASE, PubMED and Web of Science) were searched from January 2000 to November 2015. The year 2000 was chosen as a cut-off, as this is the date from which molecular subtypes of breast cancer were first defined [32]. No other date or language restrictions were imposed. The search strategy (Table 2, online only), developed in MEDLINE, was comprised of several key search terms combined with the boolean operators AND/OR aligned to relevant medical subject headings, and included various terms for 'breast cancer', 'breast conserving therapy/mastectomy', 'triple negative' and 'survival/recurrence' outcomes.

\section{Study eligibility}

Observational studies and randomised controlled trials reporting hazard ratios (HRs), odds ratios (ORs) or relative risks (RRs) and associated 95\% confidence intervals (CIs) for overall and/or locoregional/distant recurrence were included if they examined 1) breast cancer patients with triple negative (non-metastatic) disease at diagnosis who 2) clearly stratified survival/recurrence endpoints by the type of surgery (mastectomy or breast conserving therapy) received and 3) in which radiotherapy status was reported. All studies in which standardised therapy was administered were considered eligible regardless of the exact chemotherapeutic regimens (i.e.: neo-adjuvant/adjuvant) or radiotherapy protocols. A concerted effort was made to contact the authors of all potentially relevant studies to obtain effect 
estimates or counts of events by surgical/radiotherapy exposure status that were not reported in the original paper.

\section{Data collection and extraction}

Each electronic database was searched by the principal reviewer (MO'R). Three reviewers then indendently scanned the titles and abstracts of all identified papers after duplicate removal (MO'R, NB, LM). The full papers from all potentially relevant studies were then sourced and read. Data extraction was undertaken by two reviewers (MO'R, NB) using a pre-defined excel spreadsheet, recording detailed information on the origin of the study (country and year), characteristics of the population under study (study size, age and follow-up time, stage of disease), survival estimates and associated $95 \%$ Cls and covariates for adjustment in the analysis. The methodological quality of included cohort studies was assessed using the Newcastle-Ottawa scale [33] and the Cochrane risk of bias tool was used for assessing randomised trials [34].

\section{Statistical analysis}

Effect estimates and associated 95\% Cls comparing survival and recurrence outcomes stratified by surgical type (BCT or PMRT) were extracted from all relevant papers. Wherever possible we reported on multivariable adjusted effect estimates. Within studies from which an unadjusted effect estimate could be derived from the raw counts of exposed and unexposed patients, corresponding effect estimates were estimated by calculating a rate ratio in Stata using the 'CSI' command. Individual study authors were also contacted to obtain frequencies not reported in the original article. One study [24], through personal communication with the authors, provided 
anonymous individual patient data which enabled its inclusion in specific subgroup analysis. The principal quantitative synthesis involved a comparison of BCT and PMRT. Mastectomy only patients were used as the reference group in all analyses. Study-specific effect estimates were pooled using a random effects model, as described by DerSimonian and Laird [35], to account for both within-study sampling error (variance) and between-study variation. The degree of statistical heterogeniety was assessed using the Cochrane's $\mathrm{Q}$ test and the percentage variation in the effect estimate attributable to this heterogeniety was assessed using the I-squared statistic [36]. In post-hoc sensitivity analysis, the influence of each individual study was assessed by excluding each in turn and re-running the analyses monitoring for changes in heterogeniety and the overall summary estimate. Given the reported survival differences with adjuvant radiotherapy in more advanced disease $[18,22]$ and younger patients [18], planned subgroup analyses by age group (<40, 40-64, $\geq 65$ years) and early (T1-2, N0-1) and late stage (T3-4, N2-3) disease were also undertaken. Begg's rank correlation test [37] and Egger's linear regression test [38] were conducted to investigate potential small study effects or other publication biases. Stata IC v. 11.0 (StataCorp, College Station, TX, USA) was used for all analyses. 


\section{RESULTS:}

A total of 1,539 papers were identified. Of these, 1,473 were clearly irrelevant from the initial screening of their title and abstract. Upon closer inspection of the remaining 66 papers (for which the full text articles were sought), only 12 met the criteria for inclusion. Justification for subsequent study exclusions are documented in Figure 1.

Table 1 summarises the characteristics of the 12 included studies. Of these, the majority (9 out of 10) were retrospective cohort studies and two were randomised controlled trials. The methodological quality of the included cohort studies was moderate to high with a mean score of six out of a possible nine (range 4 to 8; Table 3, online only). There appeared to be a low risk of bias in the included randomised controlled trials across all domains (Table 4, online only); however, blinding of surgical procedure and radiotherapy receipt was not practicable in this context. The median follow-up period ranged between 1.9 to 7.2 years across the studies and locoregional recurrence was the most commonly assessed endpoint in 9 studies $[17,19-23,25,29,30]$. The median age at diagnosis ranged from 50 to 59 years with the largest study including 1,138 TNBC patients [18], and the two smallest $[19,30]$ consisted of 62 TNBC patients each. In 5 studies, patients who had undergone neoadjuvant chemotherapy prior to surgery were excluded $[17,19,25,29,30]$. The majority of studies were conducted in the USA or Asia.

\section{Locoregional recurrence}

Six studies $[17,19-21,29,30]$ examined locoregional recurrence in a total of 1,795 patients. Comparing BCT to mastectomy only, the pooled HR was $0.61(95 \% \mathrm{Cl}$ 
0.41, 0.90), Figure 2. Seven studies (2,487 patients) $[17,19-23,25]$ compared PMRT to mastectomy only, the pooled HR was $0.62(95 \% \mathrm{Cl} 0.44,0.86)$, Figure 2 . There was no evidence of heterogeniety in either analyses. In subgroup analysis only two studies $[17,29](1,114$ patients) examined locoregional recurrence in early-stage (T12, N0) disease. Comparing BCT to mastectomy only, the pooled HR was 0.55 (95\% $\mathrm{Cl} 0.32-0.95)$, with no evidence of heterogenity. Two additional studies $[22,23]$ compared PMRT to mastectomy alone and locoregional recurrence risk among women with late-stage disease (T3-4, N2-3), with a pooled HR of 0.32 (95\% Cl 0.160.65). No significant heterogeniety was present. No studies reported on the influence of age at diagnosis on locoregional recurrence by radiotherapy administration.

\section{Distant recurrence}

Five studies $(1,615$ patients) reported on distant recurrence $[17,19,21,29,30]$. The pooled HR comparing BCT to mastectomy only patients was HR $0.88(95 \% \mathrm{Cl} 0.63$, 1.25), Figure 3. There was no evidence of heterogeniety. Four studies $(1,059$ patients) $[17,19,21,23]$ compared PMRT to mastectomy only, the pooled HR was 1.40 (95\% Cl 0.63, 3.10), and significant heterogeniety was detected Pheterogeniety $=0.000,1^{2}=87.6 \%$, Figure 3. Only one study [29] examined distant recurrence in patient's with early-stage disease. It was not possible to examine the impact of latestage disease (T3-4, N2-3) or age at diagnosis and the risk of distant recurrence by radiotherapy receipt.

\section{Overall survival}


Six studies (3,184 patients) compared BCT to mastectomy only for overall survival [17-19,21,24,29]. The pooled HR was 0.57 (95\% Cl 0.36-0.88), Figure 4; moderate heterogeniety was present $\left(P\right.$ heterogeniety $\left.=0.07, \mathrm{I}^{2}=50.5 \%\right)$. There was little difference when the analysis was restricted to four studies $[17,18,24,29]$ with multivariable adjusted estimates HR 0.57 (95\% Cl 0.31-1.02). Comparing PMRT to mastectomy only, the pooled HR from seven studies (3,219 patients) [17-19,21,24,27,29] was $1.12(95 \% \mathrm{Cl} 0.75,1.69)$ Figure 4. Again, significant heterogeniety was present (Pheterogeniety $\left.=0.001, \mathrm{I}^{2}=77.0 \%\right)$. Four studies $(1,973$ patients $)$ examined overall survival in early-stage (T1-2, N0) disease $[17,18,24,29]$, comparing BCT to mastectomy only, with a pooled HR of $0.74(95 \% \mathrm{Cl} 0.43-1.29)$, Pheterogeniety $=0.031, \mathrm{I}^{2}$ $=66.1 \%$, Figure 5 (online only). Two further studies $[18,24]$ additionally provided an estimate of overall survival comparing PMRT to mastectomy only within T1-2, N0 tumours; pooled HR $1.10(95 \% \mathrm{Cl} 0.33-3.64)$. Both of the above studies $[18,24]$ also examined overall survival in relation to late stage disease (T3-4, N2-3). The pooled HR comparing BCT and PMRT to mastectomy only was 0.25 (95\% Cl 0.10-0.62) and $0.53(95 \% \mathrm{Cl} 0.32-0.86)$ respectively; no statistical heterogeniety was detected. There was no statistically significant interaction between disease stage and BCT/PMRT on overall survival, $P_{\text {interaction}}=0.983$. Combining data from two studies $[18,24]$, the effect of age at diagnosis on overall survival comparing PMRT and BCT to mastectomy only was examined, the corresponding pooled effect estimates were HR $0.30(95 \% \mathrm{Cl} 0.11-0.82)$ and $\mathrm{HR} 0.22(95 \% \mathrm{Cl} 0.04,1.13)$ age <40 years, HR $0.76(95 \% \mathrm{Cl} 0.37-1.58)$ and $\mathrm{HR} 0.38(95 \% \mathrm{Cl} 0.11,1.31)$ aged $40-64$ years, and HR $0.67(95 \% \mathrm{Cl} 0.14-3.18)$ and $\mathrm{HR} 0.79(95 \% \mathrm{Cl} 0.22-2.76)$ aged $\geq 65$ years respectively, Figure 6 (online only). No statistically significant interaction was detected, Pinteraction $=0.847$. 


\section{Sensitivity analyses}

For each comparison undertaken (i.e.: BCT/PMRT versus mastectomy only), in posthoc sensitivity analysis we excluded each study in turn to monitor for individual study effects on heterogeniety and the overall effect estimate. One relatively large $(n=768)$ study of stage T1-3, N0-3 patients [17], had a strong influence on the observed effect estimates for several of the outcomes studied. For locoregional recurrence (6 studies) comparing BCT to mastectomy only, removal of this one study [17], resulted in a slight attenuation of the overall effect estimate HR $0.72(95 \% \mathrm{Cl} 0.46,1.15)$, Pheterogeniety $=0.823, I^{2}=0.0 \%$. For distant recurrence comparing PMRT to mastectomy only (4 studies), the exclusion of this same study [17], attenuated the pooled estimate HR $0.94(95 \% \mathrm{Cl} 0.58-1.52) P_{\text {heterogeniety }}=0.196$ and explained much of the observed heterogeniety $\left(I^{2}=38.7 \%\right)$. For overall survival, comparing PMRT to mastectomy only (7 studies), exclusion of the study by Abdulkarim et al [17], again attenuated the pooled effect estimate HR $0.86(95 \% \mathrm{Cl} 0.72-1.02)$ and significantly lowered heterogeniety $\left(I^{2}=7.6 \%, P=0.363\right)$. The systematic removal of other studies, including those of different study designs (i.e.: randomised trial versus cohort study) or from conference proceedings only, failed to materially alter the overall pooled effect estimates or heterogeniety (data not shown).

\section{Publication bias}

Begg and Egger tests were undertaken to assess for publication and other small study biases. There was no evidence of publication/small-study bias in comparisons where locoregional recurrence or overall survival were study outcomes (data not shown). However, in comparisons of BCT to mastectomy alone for distant recurrence (5 studies), there was some evidence of publication or other small-study 
bias (Begg $p=0.221$, Egger $p=0.009)$. The resulting Egger regression plot showed deviation of the intercept from zero, indicating marked asymmetry with relatively few studies of higher precision. 


\section{DISCUSSION:}

There is a paucity of studies that have examined the prognostic impact of adjuvant radiotherapy in breast cancer patients with triple negative disease. The findings from this study show that administration of adjuvant radiotherapy confers a locoregional recurrence-free survival benefit in TNBC, irrespective of the type of surgery initially received. The administration of adjuvant radiotherapy was not significantly associated with distant recurrence, and there was no consistent overall survival benefit observed between locoregional treatment groups.

Previous studies evaluating the value of radiotherapy in TNBC patients have shown conflicting results. A study of 768 patients from a comprehensive cancer centre in a single Canadian province, reported an increased risk of locoregional recurrence in T1-2, NO TNBC patients treated with mastectomy only in comparison to those receiving $\mathrm{BCT}$, suggesting that adjuvant radiotherapy may be an important factor in optimising local control; however there was no observed difference in overall survival [17]. Conversely, a retrospective study of 646 T1-2, NO TNBC patients in the USA, reported no significant difference in locoregional recurrence between patients receiving BCT or mastectomy [29]. Several other studies which also included patients with more advanced cancer stages showed that BCT administration was associated with lower risk of locoregional recurrence than mastectomy alone, albeit not achieving statistical significance $[20,21,30]$. It is however likely that these studies were underpowered due to their small sample size.

A prospective, randomised controlled multi-centre study, which was conducted in the era before TNBC was recognised as a specific entity, had documented that in 
women with stage I or stage II TNBC undergoing mastectomy, administration of radiotherapy combined with chemotherapy, was associated with superior local recurrence-free survival compared to chemotherapy alone [27]. In a study from the Danish Breast Cancer Co-operative Group 82 b and c trials, Kyndi et al [23] examined the impact of breast cancer subtypes on PMRT response. The trial included data from 152 TNBC patients with high-risk disease (i.e.: either positive lymph nodes or T3/4 disease), 74 of which were randomised to receive PMRT. In multivariable analysis, the authors reported significantly smaller locoregional recurrence reductions in the TNBC subtype. While the authors suggested that this was perhaps a result of increased radioresistance in these tumours, these results may be explained by the higher mitotic index and aggressive clinical course of TNBCs, which may not necessarily be radioresistant [17]. Moreover, the predisposition to BRCA mutations in TNBC patients, which renders the tumour defective in DNA repair, has been argued as a mechanism for increased radiosensitivity [12]. A prospective single institutional study of 77 TNBC patients with T1-4, N0-2 tumours in the USA [21] had found that women who did not undergo PMRT had a significantly higher risk of locoregional recurrence. Corroborating these findings, a retrospective analysis of 553 TNBC patients from a single institution in Shanghai, Chen et al [22] also reported that the addition of PMRT to the treatment of patients with high-risk disease (stage T3-4, N2-3) led to superior locoregional recurrence outcomes; a finding which compliments the results of the present metaanalysis.

Recently, the Early Breast Cancer Trialists' Collaborative Group (EBCTCG) conducted a meta-analysis of individual patient data from 22 randomised trials 
including over 8,000 women [39]. Whilst not specifically reporting on patients with TNBC, this study found that PMRT among women with one to three positive axillary nodes, significantly reduced not only locoregional, but also distant recurrence, even when systemic therapy was given [39]. In line with this evidence, Kyndi et al [23] using data from the Danish Breast Cancer Co-operative Group trials, reported a significant increased risk of distant recurrence among TNBC patients not receiving PMRT. However, other studies have shown non-significant increased risks of distant recurrence in patients undergoing PMRT compared to mastectomy only $[17,19,21]$. In pooled analysis in the present study, distant recurrence was not significantly associated with either PMRT or BCT in comparison to patients recieving mastectomy only. The absence of any clear effect may be attributable to the small number of studies (low power) examining this endpoint.

In this meta-analysis, radiation therapy does not appear to be consistently associated with an overall survival benefit in TNBCs. This is in view of the fact that we only observed a higher overall survival in patients subjected to BCT compared to mastectomy only, but not in patients undergoing PMRT. Steward et al [24] conducted a retrospective investigation of 468 patients with stage I-III (T1-4, N0-3) TNBC from a single USA centre. Similar to the current findings, the authors only found a survival benefit associated with radiotherapy in women undergoing breast conservation and not in those receiving mastectomy. This observation may be partly explained by the underlying differences in patient selection for type of surgery, whereby breast conserving surgery is typically indicated for patients with smaller tumours (T1-2) [40], and conceivably a better baseline prognosis [41]. This notion is supported by the findings of the present meta-analysis, wherein the initial survival benefit associated 
with BCT compared to mastectomy in all-stage patients was attenuated and nonsignificant within patients with very early stage disease (T1-2, N0 tumours).

Based on the pooled HRs from the current meta-analysis there was a suggestion of a stronger overall survival benefit associated with BCT compared to mastectomy alone in women with late-stage disease (T3-4, N2-3) and younger age at diagnosis ( $<40$ years). However, these findings should be interpreted with caution as we found no evidence of effect modification by stage or age, perhaps owing to the small number of studies available for stratified analyses. Further prospective studies in these subgroups are warranted. Whilst the mechanism for a preferential overall survival benefit of adjuvant radiotherapy in younger patients is unknown, one potential explanation may be that the presence of underlying BRCA gene mutation in these patients may have influenced RT response [42], as it is suggested that tumours that arise in BRCA carriers are likely to be more sensitive to the effects of ionizing radiation [43].

A strength of the present analysis was the stratification of TNBC patients according to locoregional management (i.e.: BCT versus PMRT), as patients with a less favourable prognosis may be more likely to receive PMRT than BCT [41], making it inappropriate to classify the BCT and PMRT as a composite adjuvant radiotherapy group. In planned subgroup analysis, we attempted to ascertain differences in response to adjuvant radiotherapy by both stage of disease and age at diagnosis. The average follow-up time among the 12 included studies in this systematic review was 4.6 years (range 1.9-7.2), although in two studies follow-up was under 3 years $[20,21]$. Accounting for other known prognostic factors, it has been previously 
reported that TNBCs exhibit a distinctive early pattern of recurrence, peaking at 2-3 years, with the majority occurring within the first 5 years [44]. Therefore, the followup periods in the majority of the included studies in the present review are likely adequate to determine their intended survival endpoints.

The limitations of this systematic review principally relate to the fact that it is not a meta-analysis of individual patient data and that there were only a small number of contributing studies, which were often limited by the lack of details reported in the original publication. Wherever possible, efforts were made to contact the authors of the original paper to obtain stratified frequencies of events by type of surgery and radiotherapy receipt. In all, 16 authors were contacted by e-mail for data requests. Of the 7 replies received, only 2 authors provided additional information [19,24]. Of note, two of the studies included in the present analysis were from conference proceedings only $[20,30]$ and two were randomised controlled trials $[23,27]$. However, their exclusion in post-hoc sensitivity analysis did not materially alter the pooled findings. The majority of included studies were single institution, retrospective, non-randomised study designs with likely differences in the clinical and pathologic characteristics of their patient populations (Table 1). This may have inevitably contributed to the observed high heterogeneity in certain estimates.

It is also important to note that the TNBC subtype per se, is not in itself an indication for post-mastectomy radiotherapy [45], and that the decision to irradiate is influenced by many factors including tumour-related prognostic features (i.e.: involved margins, larger tumour size, positive lymph node status, lymphovascular invasion), patientrelated factors (i.e.: socioeconomic status, patient preference/values) and health 
system-related factors (physician-preference/values, availability of radiotherapy machines). Whilst some of these aspects were accounted for in the analyses of several studies included in the current meta-analysis, other factors are inherently difficult to capture and may have impacted our findings to some extent.

While it is conceivable that systemic treatment may have varied between the different settings where the studies in this review were conducted, it is felt that this may not have influenced the results to a great extent. This review addresses patients with non-metastatic triple negative breast cancer, in whom the (global) standard of care for neoadjuvant/adjuvant treatment during the study period was anthracycline +/- taxane based chemotherapy, to which TNBCs have been shown to be particularly sensitive [46]. Dose intensity may well have differed between the different study populations, particularly in Asia [47]. However, other than specifying chemotherapy regimen, this information was not available in the studies included in the current review. Only five studies reported the exclusion of patients who had undergone neoadjuvant chemotherapy prior to surgery $[17,19,25,29,30]$. This may be particularly important to bear in mind, as the response to neo-adjuvant treatment may differentially affect the patterns of recurrence and overall survival in TNBC patients [48]. Many included studies whilst reporting on the raw frequencies of outcomes by type of surgery and radiotherapy use, did not conduct multivariable survival analysis. In such studies, we calculated an unadjusted risk ratio, which unfortunately leaves open the potential for confounding.

In summary, this systematic review and meta-analysis shows that adjuvant radiotheray, irrespective of the extent of initial breast surgery, is associated with 
locoregional recurrence benefits in patients with TNBC. However radiotherapy, was not consistently associated with an improvement in overall survival. While subgroup analyses seem to suggest that adjuvant radiotherapy may be more strongly associated with an overall survival gain in patients with T3-4,N2-3 tumors, as well as in women aged less than 40 years, these observations need to be interpreted with caution in light of the small number of contributing studies, and absence of effect modification by stage, and age at diagnosis. There is hence a need, for future prospective clinical trials to assess the role of adjuvant radiotherapy in TNBC subgroups who currently fall outside the remit of conventional radiotherapy guidelines. In future work, the authors plan to conduct an individual participant data meta-analysis to improve understanding on the continued debate of adjuvant radiotherapy in TNBC.

\section{Acknowledgements:}

We wish to thank those authors who were able to provide us with additional data for inclusion in this systematic review. At the time of writing, MO'R was supported through a Cancer Research UK population research committee postdoctoral fellowship [A16601]. NB was financially supported by the Ministry of Higher Education Malaysia (High Impact Research Grant [UM.C/HIR/MOHE/06]).

\section{REFERENCES:}

[1] Dawood S. Triple-negative breast cancer: epidemiology and management options. Drugs 2010;70:2247-58. doi:10.2165/11538150-000000000-00000.

[2] Boyle P. Triple-negative breast cancer: epidemiological considerations and recommendations. Ann Oncol 2012;23 Suppl 6:vi7-12. 
doi:10.1093/annonc/mds187.

[3] Anders CK, Carey LA. Biology, metastatic patterns, and treatment of patients with triple-negative breast cancer. Clin Breast Cancer 2009;9 Suppl 2:S73-81. doi:10.3816/CBC.2009.s.008.

[4] Khan AJ, Milgrom SA, Barnard N, Higgins SA, Moran M, Shahzad H, et al. Basal subtype, as approximated by triple-negative phenotype, is associated with locoregional recurrence in a case-control study of women with 0-3 positive lymph nodes after mastectomy. Ann Surg Oncol 2014;21:1963-8. doi:10.1245/s10434-014-3512-1.

[5] Caudle AS, Tereffe W, Mittendorf EA. Should Local Therapy for Invasive Breast Cancer Be Customized on the Basis of Subtype? Curr Breast Cancer Rep 2013;5:145-51. doi:10.1007/s12609-013-0103-2.

[6] Eiermann W, Vallis KA. Locoregional treatments for triple-negative breast cancer. Ann Oncol 2012;23 Suppl 6:vi30-4. doi:10.1093/annonc/mds192.

[7] Conte P, Guarneri V. Triple-negative breast cancer: current management and future options. Eur J Cancer Suppl 2009;7:14-8. doi:10.1016/S13596349(09)70005-9.

[8] Goldhirsch A, Winer EP, Coates AS, Gelber RD, Piccart-Gebhart M, Thürlimann B, et al. Personalizing the treatment of women with early breast cancer: highlights of the St Gallen International Expert Consensus on the Primary Therapy of Early Breast Cancer 2013. Ann Oncol 2013;24:2206-23. doi:10.1093/annonc/mdt303.

[9] Truong PT, Olivotto IA, Whelan TJ, Levine M. Clinical practice guidelines for the care and treatment of breast cancer: 16. Locoregional post-mastectomy radiotherapy. CMAJ 2004;170:1263-73. 
[10] Recht A, Edge SB, Solin LJ, Robinson DS, Estabrook A, Fine RE, et al. Postmastectomy radiotherapy: clinical practice guidelines of the American Society of Clinical Oncology. J Clin Oncol 2001;19:1539-69.

[11] Lowery AJ, Kell MR, Glynn RW, Kerin MJ, Sweeney KJ. Locoregional recurrence after breast cancer surgery: a systematic review by receptor phenotype. Breast Cancer Res Treat 2012;133:831-41. doi:10.1007/s10549011-1891-6.

[12] Moran MS. Radiation therapy in the locoregional treatment of triple-negative breast cancer. Lancet Oncol 2015;16:e113-22. doi:10.1016/S14702045(14)71104-0.

[13] Overgaard M, Nielsen HM, Overgaard J. Is the benefit of postmastectomy irradiation limited to patients with four or more positive nodes, as recommended in international consensus reports? A subgroup analysis of the DBCG 82 b\&c randomized trials. Radiother Oncol 2007;82:247-53. doi:10.1016/j.radonc.2007.02.001.

[14] Wahba HA, El-Hadaad HA. Current approaches in treatment of triple-negative breast cancer. Cancer Biol Med 2015;12:106-16. doi:10.7497/j.issn.20953941.2015 .0030$.

[15] Pignol J-P, Rakovitch E, Olivotto IA. Is breast conservation therapy superior to mastectomy for women with triple-negative breast cancers? J Clin Oncol 2011;29:2841-3. doi:10.1200/JCO.2011.35.8838.

[16] Kent C, Horton J, Blitzblau R, Koontz BF. Whose disease will recur after mastectomy for early stage, node-negative breast cancer? A systematic review. Clin Breast Cancer 2015. doi:10.1016/j.clbc.2015.06.008.

[17] Abdulkarim BS, Cuartero J, Hanson J, Deschênes J, Lesniak D, Sabri S. 
Increased risk of locoregional recurrence for women with T1-2N0 triplenegative breast cancer treated with modified radical mastectomy without adjuvant radiation therapy compared with breast-conserving therapy. J Clin Oncol 2011;29:2852-8. doi:10.1200/JCO.2010.33.4714.

[18] Bhoo-Pathy N, Verkooijen HM, Wong F-Y, Pignol J-P, Kwong A, Tan E-Y, et al. Prognostic role of adjuvant radiotherapy in triple-negative breast cancer: A historical cohort study. Int J Cancer 2015. doi:10.1002/ijc.29617.

[19] Cruz RP, Pedrini JL, Zettler CG, Savaris RF, Grassi V. How to identify patients with increased risk of breast cancer relapse? Appl Immunohistochem Mol Morphol 2014;22:488-97. doi:10.1097/PAI.0b013e3182915951.

[20] Eastman A, Tammaro Y, Andrews V, Euhus D, Huth J, Leitch M, et al. BreastConserving Therapy vs Total Mastectomy in Triple-Negative Breast Cancer. 13th Annu. Meet. Am. Soc. Breast Surg., 2012, p. 44.

[21] Dragun AE, Pan J, Rai SN, Kruse B, Jain D. Locoregional recurrence in patients with triple-negative breast cancer: preliminary results of a single institution study. Am J Clin Oncol 2011;34:231-7. doi:10.1097/COC.0b013e3181dea993.

[22] Chen X, Yu X, Chen J, Yang Z, Shao Z, Zhang Z, et al. Radiotherapy can improve the disease-free survival rate in triple-negative breast cancer patients with T1-T2 disease and one to three positive lymph nodes after mastectomy. Oncologist 2013;18:141-7. doi:10.1634/theoncologist.2012-0233.

[23] Kyndi M, Sørensen FB, Knudsen H, Overgaard M, Nielsen HM, Overgaard J. Estrogen receptor, progesterone receptor, HER-2, and response to postmastectomy radiotherapy in high-risk breast cancer: the Danish Breast Cancer Cooperative Group. J Clin Oncol 2008;26:1419-26. 
doi:10.1200/JCO.2007.14.5565.

[24] Steward LT, Gao F, Taylor MA, Margenthaler JA. Impact of radiation therapy on survival in patients with triple-negative breast cancer. Oncol Lett 2014;7:548-52. doi:10.3892/ol.2013.1700.

[25] Tseng YD, Uno H, Hughes ME, Niland JC, Wong $\mathrm{Y}-\mathrm{N}$, Theriault $\mathrm{R}$, et al. Biological Subtype Predicts Risk of Locoregional Recurrence After Mastectomy and Impact of Postmastectomy Radiation in a Large National Database. Int J Radiat Oncol Biol Phys 2015;93:622-30. doi:10.1016/j.jijrobp.2015.07.006.

[26] Voduc KD, Cheang MCU, Tyldesley S, Gelmon K, Nielsen TO, Kennecke H. Breast cancer subtypes and the risk of local and regional relapse. J Clin Oncol 2010;28:1684-91. doi:10.1200/JCO.2009.24.9284.

[27] Wang J, Shi M, Ling R, Xia Y, Luo S, Fu X, et al. Adjuvant chemotherapy and radiotherapy in triple-negative breast carcinoma: a prospective randomized controlled multi-center trial. Radiother Oncol 2011;100:200-4. doi:10.1016/j.radonc.2011.07.007.

[28] Yadav S, Jawad M, Wobb J, Wilkinson B, Yadav D, Wallace M, et al. Outcomes of patients with triple-negative breast cancer treated with radiation therapy. J Clin Oncol 2014;32:abstract 88.

[29] Zumsteg ZS, Morrow M, Arnold B, Zheng J, Zhang Z, Robson M, et al. Breastconserving therapy achieves locoregional outcomes comparable to mastectomy in women with T1-2N0 triple-negative breast cancer. Ann Surg Oncol 2013;20:3469-76. doi:10.1245/s10434-013-3011-9.

[30] Ly B, Kwon D, Reis I, Jauhari S, Wright J, Gunaseelan V, et al. Comparison of Clinical Outcomes in Early Stage Triple Negative Breast Cancer Treated With 
Mastectomy Versus Breast Conserving Therapy. Int J Radiat Oncol 2012;84:S258-9. doi:10.1016/j.ijrobp.2012.07.673.

[31] Moher D, Liberati A, Tetzlaff J, Altman DG. Preferred reporting items for systematic reviews and meta-analyses: the PRISMA statement. Int J Surg 2010;8:336-41. doi:10.1016/j.ijsu.2010.02.007.

[32] Perou CM, Sørlie T, Eisen MB, van de Rijn M, Jeffrey SS, Rees CA, et al. Molecular portraits of human breast tumours. Nature 2000;406:747-52. doi:10.1038/35021093.

[33] Wells G, Shea B, O'Connell D, Peterson J, Welch V, Losos M, et al. The Newcastle-Ottawa Scale (NOS) for assessing the quality of nonrandomised studies in meta-analysis 2011. http://www.ohri.ca/programs /clinical_epidemiology/oxford.asp. (accessed October 1, 2015).

[34] Higgins JPT, Altman DG, Gøtzsche PC, Jüni P, Moher D, Oxman AD, et al. The Cochrane Collaboration's tool for assessing risk of bias in randomised trials. BMJ 2011;343:d5928. doi:10.1136/bmj.d5928.

[35] DerSimonian R, Laird N. Meta-analysis in clinical trials. Control Clin Trials $1986 ; 7: 177-88$.

[36] Higgins JPT, Thompson SG, Deeks JJ, Altman DG. Measuring inconsistency in meta-analyses. BMJ 2003;327:557-60. doi:10.1136/bmj.327.7414.557.

[37] Begg CB, Mazumdar M. Operating characteristics of a rank correlation test for publication bias. Biometrics 1994;50:1088-101.

[38] Egger M, Davey Smith G, Schneider M, Minder C. Bias in meta-analysis detected by a simple, graphical test. BMJ 1997;315:629-34.

[39] EBCTCG (Early Breast Cancer Trialists' Collaborative Group), McGale P, Taylor C, Correa C, Cutter D, Duane F, et al. Effect of radiotherapy after 
mastectomy and axillary surgery on 10-year recurrence and 20-year breast cancer mortality: meta-analysis of individual patient data for 8135 women in 22 randomised trials. Lancet 2014;383:2127-35. doi:10.1016/S01406736(14)60488-8.

[40] Newman LA, Kuerer HM. Advances in breast conservation therapy. J Clin Oncol 2005;23:1685-97. doi:10.1200/JCO.2005.09.046.

[41] Morrow M, White J, Moughan J, Owen J, Pajack T, Sylvester J, et al. Factors Predicting the Use of Breast-Conserving Therapy in Stage I and II Breast Carcinoma. J Clin Oncol 2001;19:2254-62.

[42] Trainer AH, James PA, Mann GB, Lindeman GJ. Breast conservation versus mastectomy in triple-negative breast cancer: two steps forward, one step back? J Clin Oncol 2011;29:4722-3; author reply 4723-4. doi:10.1200/JCO.2011.38.9684.

[43] Powell SN, Kachnic LA. Roles of BRCA1 and BRCA2 in homologous recombination, DNA replication fidelity and the cellular response to ionizing radiation. Oncogene 2003;22:5784-91. doi:10.1038/sj.onc.1206678.

[44] Dent R, Trudeau M, Pritchard KI, Hanna WM, Kahn HK, Sawka CA, et al. Triple-negative breast cancer: clinical features and patterns of recurrence. Clin Cancer Res 2007;13:4429-34. doi:10.1158/1078-0432.CCR-06-3045.

[45] Moran MS. Should triple-negative breast cancer (TNBC) subtype affect localregional therapy decision making? Am Soc Clin Oncol Educ Book 2014:e32-6. doi:10.14694/EdBook_AM.2014.34.e32.

[46] Yadav BS, Sharma SC, Chanana P, Jhamb S. Systemic treatment strategies for triple-negative breast cancer. World J Clin Oncol 2014;5:125-33. doi:10.5306/wjco.v5.i2.125. 
[47] Bhoo-Pathy N, Yip C-H, Hartman M, Uiterwaal CSPM, Devi BCR, Peeters PHM, et al. Breast cancer research in Asia: Adopt or adapt Western knowledge? Eur J Cancer 2013;49:703-9. doi:10.1016/j.ejca.2012.09.014.

[48] Yang TJ, Morrow M, Modi S, Zhang Z, Krause K, Siu C, et al. The Effect of Molecular Subtype and Residual Disease on Locoregional Recurrence in Breast Cancer Patients Treated with Neoadjuvant Chemotherapy and Postmastectomy Radiation. Ann Surg Oncol 2015. doi:10.1245/s10434-0154697-7.

\section{LEGENDS:}

Table 1: Characteristics of included studies

Figure 1: Flow diagram illustrating study identification, selection and inclusion.

Figure 2: Forest plots of locoregional recurrence comparing breast conserving therapy or post mastectomy radiotherapy to patients receiving mastectomy only.

Figure 3: Forest plots of distant recurrence comparing breast conserving therapy or post mastectomy radiotherapy to patients receiving mastectomy only.

Figure 4: Forest plots of overall survival comparing breast conserving therapy or post mastectomy radiotherapy to patients receiving mastectomy only.

Figure 5 (online only): Forest plot of overall survival comparing breast conserving therapy to mastectomy only in a subgroup of patients with early and late-stage disease.

Figure 6 (online only): Forest plot of overall survival comparing post-mastectomy radiotherapy and breast conserving therapy to mastectomy only by age group 
Table 1: Characteristics of included studies

\begin{tabular}{|c|c|c|c|c|c|c|c|c|c|}
\hline $\begin{array}{l}\text { Study ID \& } \\
\text { country/region }\end{array}$ & Study design & TNBC study population & $\begin{array}{l}\text { Study } \\
\text { size }\end{array}$ & $\begin{array}{l}\text { Age } \\
\text { (years) }\end{array}$ & $\begin{array}{l}\text { Follow- } \\
\text { up time } \\
\text { (years) }\end{array}$ & $\begin{array}{l}\text { Stage } \\
\text { of } \\
\text { disease }\end{array}$ & $\begin{array}{l}\text { Survival } \\
\text { estimates }\end{array}$ & Chemotherapy & Adjustments \\
\hline $\begin{array}{l}\text { Abdulkarim } \\
2011[17] \\
\text { Canada }\end{array}$ & $\begin{array}{l}\text { Retrospective } \\
\text { cohort study }\end{array}$ & $\begin{array}{l}\text { Newly diagnosed TNBC } \\
\text { from Jan } 1998 \text { and Dec } \\
2008 \text { in a single cancer } \\
\text { centre (Alberta). }\end{array}$ & 768 & $\begin{array}{l}\text { Median: } \\
56\end{array}$ & $\begin{array}{l}\text { Median: } \\
7.2\end{array}$ & $\begin{array}{l}\text { T1-3, } \\
\text { N0-2 }\end{array}$ & $\begin{array}{l}\text { OS, LRR, } \\
\text { DM }\end{array}$ & $\begin{array}{l}\text { Excluded } \\
\text { patients with } \\
\text { NCT. } \\
85 \% \text { CT }\end{array}$ & $\begin{array}{l}\text { Tumour size, grade, LN } \\
\text { status, LVI, chemotherapy }\end{array}$ \\
\hline $\begin{array}{l}\text { Bhoo-Pathy } \\
2015 \text { [18] Asia }\end{array}$ & $\begin{array}{l}\text { Retrospective } \\
\text { cohort study }\end{array}$ & $\begin{array}{l}\text { Non-metastatic TNBC } \\
\text { patients from hospital-based } \\
\text { cancer registries in five } \\
\text { Asian centres (University } \\
\text { Malaya Medical Centre, } \\
\text { Malaysia, National Cancer } \\
\text { Centre, Singapore, National } \\
\text { University Hospital, } \\
\text { Singapore, Tan Tock Seng } \\
\text { Hospital, Singapore, and } \\
\text { Queen Mary and Tung Wah } \\
\text { Hospital, Hong Kong) } \\
\text { diagnosed between } 2006 \\
\text { and } 2011 .\end{array}$ & 1,138 & $\begin{array}{l}\text { Median: } \\
53\end{array}$ & $\begin{array}{l}\text { Median: } \\
3.6\end{array}$ & $\begin{array}{l}\text { T1-4, } \\
\text { N0-3 }\end{array}$ & OS & $\begin{array}{l}13 \% \text { NCT } \\
75.8 \% \text { CT }\end{array}$ & $\begin{array}{l}\text { Centre (UMMC, NUH, } \\
\text { NCCS, TTSH, QMTWH), age } \\
\text { at diagnosis, race, tumour } \\
\text { size at diagnosis, number of } \\
\text { positive axillary lymph } \\
\text { nodes, tumour grade (low, } \\
\text { moderate, high), surgical } \\
\text { margins (free, involved), } \\
\text { lymphovascular invasion } \\
\text { (present, absent), neo- } \\
\text { adjuvant chemotherapy (yes, } \\
\text { no) and adjuvant } \\
\text { chemotherapy administration } \\
\text { and regimen (none, first } \\
\text { generation, second } \\
\text { generation, third generation). }\end{array}$ \\
\hline $\begin{array}{l}\text { Chen } 2013 \text { [22] } \\
\text { China }\end{array}$ & $\begin{array}{l}\text { Retrospective } \\
\text { cohort study }\end{array}$ & $\begin{array}{l}\text { TNBC from a single } \\
\text { institution (Fudan University, } \\
\text { Shanghai Cancer Centre, } \\
\text { Shanghai China) diagnosed } \\
\text { between the } 1^{\text {st } J a n u a r y ~} \\
2000 \text { and the } 31^{\text {st July } 2007 .}\end{array}$ & 553 & 52 & 5.4 & $\begin{array}{l}\text { T1-4, } \\
\text { N0-3 }\end{array}$ & LRR, DFS & $\begin{array}{l}88 \% \text { CT } \\
\% \text { NCT NR }\end{array}$ & $\begin{array}{l}\text { Age, PMRT treatment, } \\
\text { Lymphovascular invasion, } \\
\text { grade, tumour size, lymph } \\
\text { node status ( } 4 \text { or more } \\
\text { positive vs. one to three } \\
\text { positive), and chemotherapy } \\
\text { regimen. }\end{array}$ \\
\hline
\end{tabular}




\begin{tabular}{|c|c|c|c|c|c|c|c|c|c|}
\hline $\begin{array}{l}\text { Study ID \& } \\
\text { country/region }\end{array}$ & Study design & TNBC study population & $\begin{array}{l}\text { Study } \\
\text { size } \\
\text { (TNBC } \\
\text { cases) }\end{array}$ & $\begin{array}{l}\text { Age } \\
\text { (years) }\end{array}$ & $\begin{array}{l}\text { Follow- } \\
\text { up time } \\
\text { (years) }\end{array}$ & $\begin{array}{l}\text { Stage } \\
\text { of } \\
\text { disease }\end{array}$ & $\begin{array}{l}\text { Survival } \\
\text { estimates }\end{array}$ & Chemotherapy & Adjustments \\
\hline $\begin{array}{l}\text { Cruz } 2014 \text { [19] } \\
\text { Brazil }\end{array}$ & $\begin{array}{l}\text { Retrospective } \\
\text { cohort study }\end{array}$ & $\begin{array}{l}\text { TNBC patients submitted to } \\
\text { surgical treatment from Jan } \\
2000 \text { and Dec } 2005 \text { at one } \\
\text { University hospital (Hospital } \\
\text { Santa Casa de Misericordia } \\
\text { de Porto Alegre, Brazil). }\end{array}$ & 62 & NR & $\begin{array}{l}\text { Average: } \\
4.8\end{array}$ & $\begin{array}{l}\text { T1-4, } \\
\text { N0-3 }\end{array}$ & $\begin{array}{l}\text { OS, LRR, } \\
\text { DM }\end{array}$ & $\begin{array}{l}\text { Excluded } \\
\text { patients with } \\
\text { NCT. } \\
85.7 \% \text { CT }\end{array}$ & Unadjusted \\
\hline $\begin{array}{l}\text { Dragun } 2011 \\
\text { [21] USA }\end{array}$ & $\begin{array}{l}\text { Prospective } \\
\text { cohort study }\end{array}$ & $\begin{array}{l}\text { Prospective study of non- } \\
\text { metastatic TNBC patients } \\
\text { undergoing treatment } \\
\text { between } 2004-2009 \text { from the } \\
\text { University of Louisville's } \\
\text { James Graham Brown } \\
\text { Cancer Centre. }\end{array}$ & 77 & 50 & 1.9 & $\begin{array}{l}\text { T1-T4, } \\
\text { NO-N2 }\end{array}$ & $\begin{array}{l}\text { OS, LRR, } \\
\text { DM }\end{array}$ & $\begin{array}{l}32.5 \% \text { NCT } \\
55.8 \% \text { CT }\end{array}$ & Unadjusted \\
\hline $\begin{array}{l}\text { Eastman } 2012^{*} \\
{[20] \text { USA }}\end{array}$ & $\begin{array}{l}\text { Retrospective } \\
\text { cohort study }\end{array}$ & $\begin{array}{l}\text { Retrospective review of } \\
\text { patients with TNBC } \\
\text { undergoing treatment } \\
\text { between Jan } 2004 \text { and Jan } \\
2011 \text { in a comprehensive, } \\
\text { multidisciplinary breast } \\
\text { oncology programme at the } \\
\text { University of Texas, Dallas, } \\
\text { USA. }\end{array}$ & 180 & NR & $\begin{array}{l}\text { Median: } \\
2.5\end{array}$ & $\begin{array}{l}\text { T1-4, } \\
\text { N0-3 }\end{array}$ & LRR & NR & Unadjusted \\
\hline $\begin{array}{l}\text { Kyndi } 2008 \text { [23] } \\
\text { Denmark }\end{array}$ & $\begin{array}{l}\text { Randomised } \\
\text { Controlled } \\
\text { Trial }\end{array}$ & $\begin{array}{l}\text { Patients diagnosed from } \\
1982 \text { to } 1990 \text { with high-risk } \\
\text { breast cancer enrolled onto } \\
\text { the Danish Breast Cancer } \\
\text { Collaborative Group Trial } 82 \\
\text { B \& C (pre-menopausal and } \\
\text { menopausal women } \\
\text { respectively). }\end{array}$ & 152 & NR & NR & $\begin{array}{l}\text { T3-4, } \\
\text { N1-3 }\end{array}$ & LRR, DM & NR & Unadjusted \\
\hline Ly 2012* [30] & Retrospective & $\begin{array}{l}\text { Retrospective study of } \\
\text { TNBC patients with early }\end{array}$ & 62 & NR & 3.3 & T1-2, & LRR, DM & $\begin{array}{l}\text { Excluded } \\
\text { patients with }\end{array}$ & Unadjusted \\
\hline
\end{tabular}




\begin{tabular}{|c|c|c|c|c|c|c|c|c|c|}
\hline $\begin{array}{l}\text { Study ID \& } \\
\text { country/region }\end{array}$ & Study design & TNBC study population & $\begin{array}{l}\begin{array}{l}\text { Study } \\
\text { size }\end{array} \\
\text { (TNBC } \\
\text { cases) }\end{array}$ & $\begin{array}{l}\text { Age } \\
\text { (years) }\end{array}$ & $\begin{array}{l}\text { Follow- } \\
\text { up time } \\
\text { (years) }\end{array}$ & $\begin{array}{l}\text { Stage } \\
\text { of } \\
\text { disease }\end{array}$ & $\begin{array}{l}\text { Survival } \\
\text { estimates }\end{array}$ & Chemotherapy & Adjustments \\
\hline USA & cohort study & $\begin{array}{l}\text { stage disease treated at the } \\
\text { Jackson Memorial Hospital, } \\
\text { Miami (FL) from } 2004 \text { to } \\
2010 \text {. }\end{array}$ & & & & N0-1 & & $\begin{array}{l}\text { NCT. } \\
72.6 \% \text { CT }\end{array}$ & \\
\hline $\begin{array}{l}\text { Steward } 2014 \\
\text { [24] USA }\end{array}$ & $\begin{array}{l}\text { Retrospective } \\
\text { cohort study }\end{array}$ & $\begin{array}{l}\text { Retrospective study of } \\
\text { TNBC patients from a } \\
\text { prospectively maintained } \\
\text { database with a diagnosis of } \\
\text { stage I-III disease who were } \\
\text { treated between Jan } 1,2002 \\
\text { and Dec } 31,2009 .\end{array}$ & 468 & $\begin{array}{l}\text { Average: } \\
54\end{array}$ & $\begin{array}{l}\text { Median: } \\
4.3\end{array}$ & $\begin{array}{l}\text { T1-4, } \\
\text { N0-3 }\end{array}$ & OS & $\begin{array}{l}32 \% \text { NCT } \\
50 \% \text { CT }\end{array}$ & $\begin{array}{l}\text { A backward selection model } \\
\text { was chosen }(p<0.15) \text {. Only } \\
\text { stage }(1,2 a, 2 b, 3 \text { and } \\
\text { unknown) was significant in } \\
\text { the multivariable model. } \\
\text { Other variables considered } \\
\text { included age }(<50,>=50) \text {, } \\
\text { ethnicity, clinical T stage, } \\
\text { histology, nuclear grade and } \\
\text { nodal status. }\end{array}$ \\
\hline $\begin{array}{l}\text { Tseng } 2015 \\
\text { [25] USA }\end{array}$ & $\begin{array}{l}\text { Retrospective } \\
\text { cohort study }\end{array}$ & $\begin{array}{l}\text { Non-metastatic TNBC } \\
\text { diagnosed from } 1997 \text { to } \\
2012 \text { at one of } 9 \\
\text { participating National } \\
\text { Comprehensive Cancer } \\
\text { Network institutions } \\
\text { including: City of Hope } \\
\text { comprehensive cancer } \\
\text { centre, Dana- } \\
\text { Farber/Brigham and } \\
\text { Women's cancer centre, } \\
\text { Massachusetts General } \\
\text { Hospital, Fox Chase Cancer } \\
\text { Centre, The University of } \\
\text { Texas MD Anderson cancer } \\
\text { centre, Roswell Park cancer } \\
\text { institute, University of } \\
\text { Michigan, Ohio State } \\
\text { University comprehensive }\end{array}$ & 695 & $\begin{array}{l}\text { Average: } \\
52\end{array}$ & $\begin{array}{l}\text { Median: } \\
4.2\end{array}$ & $\begin{array}{l}\text { T1-4, } \\
\text { N0-3 }\end{array}$ & LRR & $\begin{array}{l}\text { Excluded } \\
\text { patients with } \\
\text { NCT }\end{array}$ & $\begin{array}{l}\text { Number of positive lymph } \\
\text { nodes, tumour size, surgical } \\
\text { margin. }\end{array}$ \\
\hline
\end{tabular}




\begin{tabular}{|c|c|c|c|c|c|c|c|c|c|}
\hline $\begin{array}{l}\text { Study ID \& } \\
\text { country/region }\end{array}$ & Study design & TNBC study population & $\begin{array}{l}\text { Study } \\
\text { size } \\
\text { (TNBC } \\
\text { cases) }\end{array}$ & $\begin{array}{l}\text { Age } \\
\text { (years) }\end{array}$ & $\begin{array}{l}\text { Follow- } \\
\text { up time } \\
\text { (years) }\end{array}$ & $\begin{array}{l}\text { Stage } \\
\text { of } \\
\text { disease }\end{array}$ & $\begin{array}{l}\text { Survival } \\
\text { estimates }\end{array}$ & Chemotherapy & Adjustments \\
\hline & & $\begin{array}{l}\text { cancer centre and Duke } \\
\text { comprehensive cancer } \\
\text { centre. }\end{array}$ & & & & & & & \\
\hline $\begin{array}{l}\text { Wang } 2011[27] \\
\text { China }\end{array}$ & $\begin{array}{l}\text { Randomised } \\
\text { Controlled } \\
\text { Trial }\end{array}$ & $\begin{array}{l}\text { Multi-centre trial of } \\
\text { consecutive patients with } \\
\text { TNBC stage I-II breast } \\
\text { cancer enrolled between } \\
\text { February } 2001 \text { and February } \\
2006 \text {. }\end{array}$ & 681 & NR & $\begin{array}{l}\text { Median } \\
7.2\end{array}$ & $\begin{array}{l}\text { T1-2, } \\
\text { N0-3 }\end{array}$ & OS & $54 \%$ CT & Unadjusted \\
\hline $\begin{array}{l}\text { Zumsteg } 2013 \\
\text { [29] USA }\end{array}$ & $\begin{array}{l}\text { Retrospective } \\
\text { cohort study }\end{array}$ & $\begin{array}{l}\text { TNBC patients identified } \\
\text { from clinical pathology } \\
\text { reports (an institutional } \\
\text { database). These were } \\
\text { consecutive patients treated } \\
\text { at a single institution } \\
\text { (Memorial Sloan-Kettering } \\
\text { Cancer Centre) from } 1999 \text { to } \\
2008 \text {. }\end{array}$ & 646 & $\begin{array}{l}\text { Median: } \\
59\end{array}$ & $\begin{array}{l}\text { Median } \\
6.5\end{array}$ & $\begin{array}{l}\text { T1-2, } \\
\text { NO }\end{array}$ & $\begin{array}{l}\text { OS, DM, } \\
\text { LRR, DFS }\end{array}$ & $\begin{array}{l}\text { Excluded } \\
\text { patients with } \\
\text { NCT. 81.3\% CT }\end{array}$ & $\begin{array}{l}\text { Age }(>50,<=50), \text { Race } \\
\text { (black vs non-black), T stage } \\
\text { (Tmic/T1a/T1b, T1c, T2) LVI } \\
\text { (yes vs. no), Grade (3 vs. } 1 \\
\text { or 2), Chemotherapy (yes vs. } \\
\text { no). }\end{array}$ \\
\hline
\end{tabular}

* Conference abstracts only.

$N R=$ not reported, $T N B C=$ triple negative breast cancer, $L R R=$ local regional recurrence, $D M=$ distant metastases, $D F S=$ disease-free survival, $C T=$ adjuvant chemotherapy, $N C T=$ neo-adjuvant chemotherapy, $P M R T=$ post mastectomy radiotherapy 
Table 2 (online only): Literature search strategy example MEDLINE: 1946-Week 4 October 2015, Limited to publications from 2000 onwards

1 Breast/ or Breast Neoplasms/ or Triple Negative Breast Neoplasms/

2 breast cancer.mp. [mp=title, abstract, original title, name of substance word, subject heading word, keyword heading word, protocol supplementary concept word, rare disease supplementary concept word, unique identifier]

31 or 2

4 breast conserving therapy.mp.

5 breast conserving surgery.mp. or Mastectomy, Segmental/

6 breast conservation.mp.

7 breast preservation.mp.

8 breast sparing surgery.mp.

9 wide local excision.mp.

10 lumpectomy.mp. or Mastectomy, Segmental/

11 quadrantectomy.mp.

12 Mastectomy, Subcutaneous/ or Mastectomy, Extended Radical/ or Mastectomy/ or Mastectomy, Radical/ or mastectomy.mp. or Mastectomy, Modified Radical/ or Mastectomy, Simple/

13 Fatal Outcome/ or outcome.mp.

14 Disease-Free Survival/ or Survival/ or survival.mp.

15 Recurrence/ or Neoplasm Recurrence, Local/ or recurrence.mp.

16 overall survival.mp.

17 cancer specific survival.mp.

18 cause specific survival.mp.

19 recurrence free survival.mp.

20 locoregional control.mp.

21 mortality.mp. or Mortality/

22 Disease Progression/ or progression.mp.

23 prognosis.mp. or Prognosis/

244 or 5 or 6 or 7 or 8 or 9 or 10 or 11 or 12

2513 or 14 or 15 or 16 or 17 or 18 or 19 or 20 or 21 or 22 or 23

26 basal like.mp.

27 triple negative.mp. [mp=title, abstract, original title, name of substance word, subject heading word, keyword heading word, protocol supplementary concept word, rare disease supplementary concept word, unique identifier]

2826 or 27

293 and 24 and 25 and 28

30 limit 29 to $y r=" 2000$-Current" 
Table 3 (online only): Methodological quality assessment of cohort studies [33] included in the systematic review and meta-analysis

\begin{tabular}{|c|c|c|c|c|c|c|c|c|c|c|}
\hline \multirow[b]{3}{*}{ Study ID } & \multicolumn{9}{|c|}{ Methodological quality assessment } & \multirow[b]{3}{*}{$\begin{array}{l}\text { Total } \\
\text { score } t\end{array}$} \\
\hline & \multirow[b]{2}{*}{ A } & \multicolumn{3}{|c|}{ Selection } & \multicolumn{2}{|c|}{ Comparability } & \multicolumn{3}{|c|}{ Outcome } & \\
\hline & & B & C & D & $\mathbf{E}$ & $\mathbf{F}$ & G & H & $\mathbf{I}$ & \\
\hline Abdulkarim $2011^{17}$ & - & * & * & * & * & * & * & * & - & 7 \\
\hline Bhoo-Pathy $2015^{18}$ & * & * & * & * & * & * & * & * & - & 8 \\
\hline Chen 201322 & - & * & * & * & * & * & * & * & - & 7 \\
\hline Cruz $2014^{19}$ & - & * & * & * & - & - & * & * & - & 5 \\
\hline Dragun $2011^{21}$ & - & * & * & * & - & - & * & - & * & 5 \\
\hline Eastman 201220 & - & * & * & * & - & - & * & - & - & 4 \\
\hline Ly 201230 & - & * & * & * & - & - & * & * & - & 5 \\
\hline Steward 201424 & - & * & * & * & * & * & - & * & - & 6 \\
\hline Tseng $2015^{25}$ & * & * & * & * & * & * & * & * & - & 8 \\
\hline Zumsteg $2013^{29}$ & - & * & * & * & - & * & * & * & - & 6 \\
\hline \\
\hline & & & \multirow{2}{*}{\multicolumn{8}{|c|}{$\mathrm{A}=$ Representativeness of the exposed cohort }} \\
\hline \multirow{2}{*}{\multicolumn{11}{|c|}{$\mathrm{B}=$ Selection of the non-exposed cohort }} \\
\hline \multirow{2}{*}{\multicolumn{4}{|c|}{$\begin{array}{l}C=\text { Ascertainment of exposure } \\
D=\text { Outcome of interest not present at the start }\end{array}$}} & & & & & & & \\
\hline \multirow{2}{*}{\multicolumn{11}{|c|}{$\begin{array}{l}\mathrm{D}=\text { Outcome of interest not present at the start } \\
\text { Comparability }\left(2^{*}\right):\end{array}$}} \\
\hline & & & & & & & & & & \\
\hline \multicolumn{11}{|c|}{$\frac{\text { Comparability }\left(2^{*}\right)}{E=\text { Comparability - axillary node status }}$} \\
\hline \multicolumn{11}{|c|}{$\begin{array}{l}\mathrm{E}=\text { Comparability }- \text { axillary node status } \\
\mathrm{F}=\text { Comparability }- \text { tumour size or stage }\end{array}$} \\
\hline \multicolumn{11}{|c|}{$\begin{array}{l}\text { Outcome }\left(3^{\star}\right) \text { : } \\
\text { Outity - tumour size or stage }\end{array}$} \\
\hline \multicolumn{11}{|l|}{$G=$ Assessment of outcome } \\
\hline \multicolumn{11}{|c|}{$\mathrm{H}=$ Was follow-up long enough } \\
\hline $\mathrm{I}=$ Adequacy of follow-up & & & & & & & & & & \\
\hline ooints can be & wa & & & & itto & רי & & & & \\
\hline
\end{tabular}

Table 4 (online only): Methodological quality assessment of randomised controlled trials [34] included in the systematic review and meta-analysis

\begin{tabular}{|c|c|c|c|c|c|c|c|}
\hline & \multicolumn{7}{|c|}{ Risk of bias } \\
\hline Study ID & A & $B$ & C & $\mathrm{D}$ & $E$ & $\mathrm{~F}$ & G \\
\hline Kyndi $2008^{23}$ & 4 & 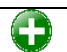 & $?$ & $?$ & 4 & 4 & 9 \\
\hline Wang $2011^{27}$ & 9 & $\varphi$ & $?$ & $?$ & 4 & 9 & 9 \\
\hline $\begin{array}{l}A=\text { Random sequence generation } \\
B=\text { Allocation concealment } \\
C=\text { Blinding of participants \& personnel } \\
D=\text { blinding of outcome assessment } \\
E=\text { Incomplete outcome data } \\
F=\text { Selective reporting } \\
G=\text { Other bias }\end{array}$ & \multicolumn{7}{|c|}{$\begin{array}{l}\text { Key: } \\
\Phi \text { Low risk of bias } \\
\text { High risk of bias } \\
\text { ?Unclear risk of bias }\end{array}$} \\
\hline
\end{tabular}


Figure 1:

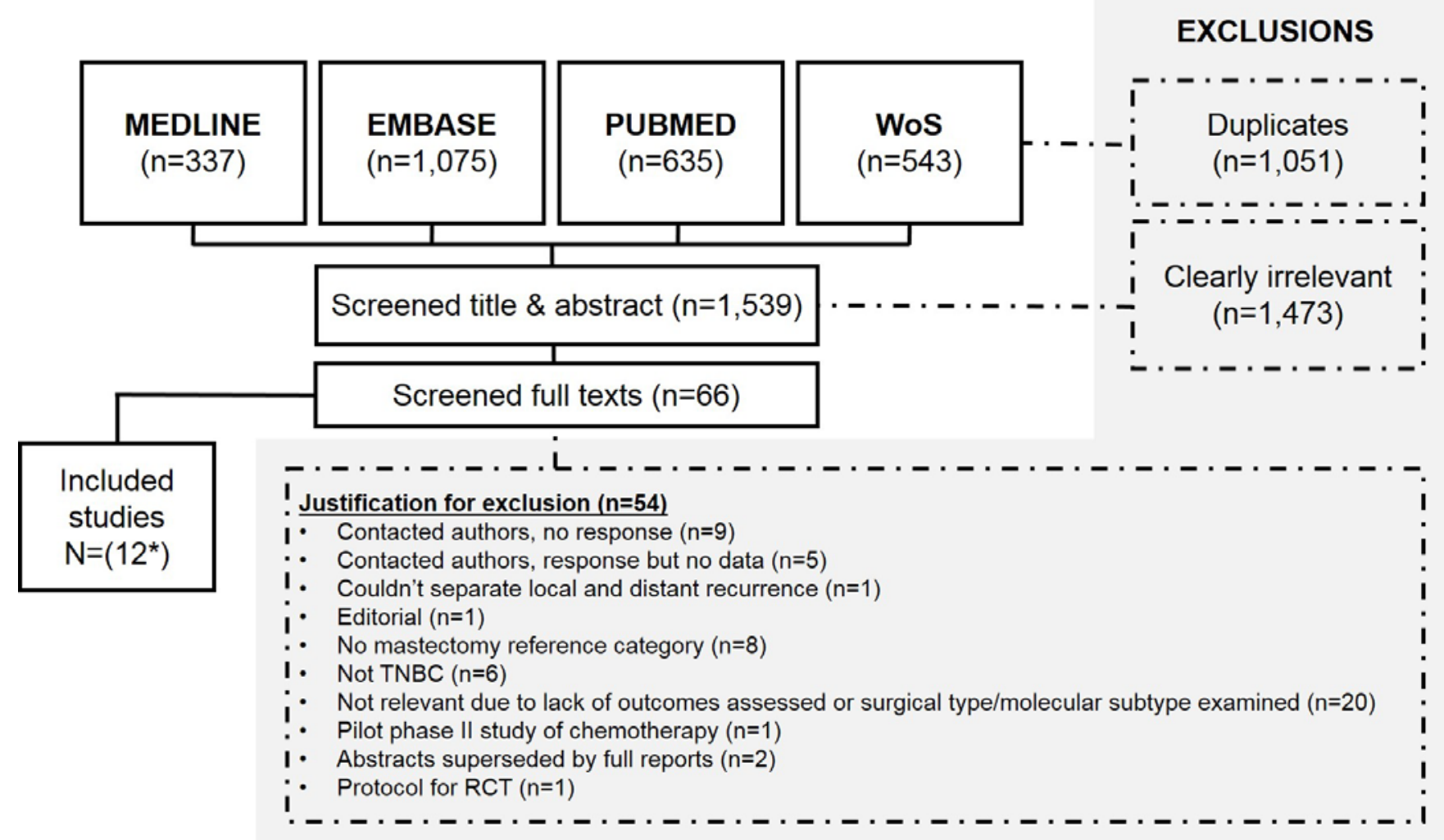

* 2 studies were from conference abstracts only 
Figure 2:

Study (ref) Year Comparison

HR $(95 \% \mathrm{Cl}) \quad$ Weight \%

Loco-regional recurrence: BCT vs. MT

$\begin{array}{lll}\text { Abdulkarim }{ }^{17} & 2011 & \text { BCT vs M (ref) } \\ \text { Cruz }^{19} & 2014 & \text { BCT vs M (ref) } \\ \text { Dragun }^{21} & 2011 & \text { BCT vs M (ref) } \\ {\text { Eastman }{ }^{20}}^{20} & 2012 & \text { BCT vs M (ref) } \\ \text { Ly }^{30} & 2012 & \text { BCT vs M (ref) } \\ \text { Zumsteg }{ }^{29} & 2013 & \text { BCT vs M (ref) }\end{array}$

Overall ( $\mathrm{I}$-squared $=\mathbf{0 . 0 \%}, \mathrm{p}=\mathbf{0 . 6 0 9}$ )

(Total patients $n=1,795$ )

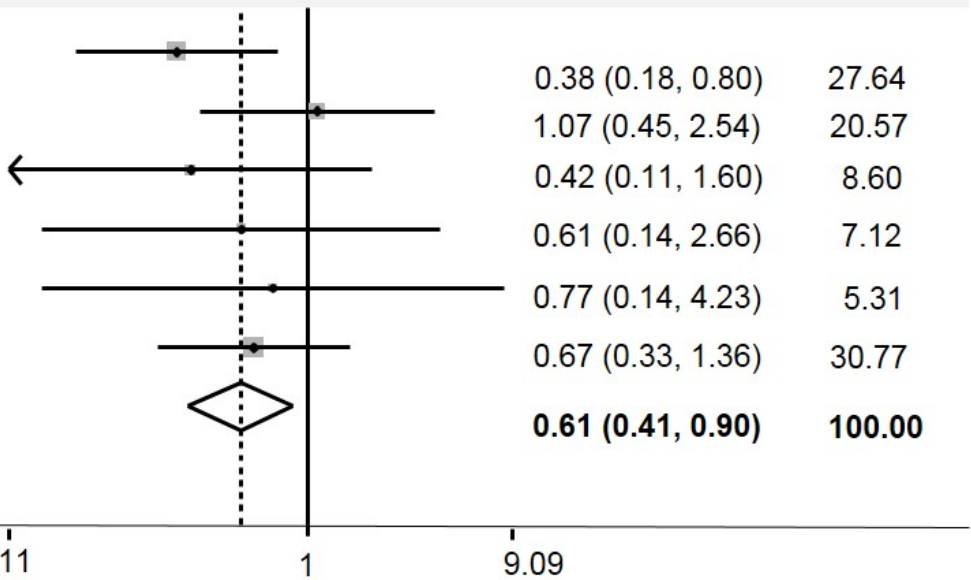

Loco-regional recurrence: PMRT vs. MT

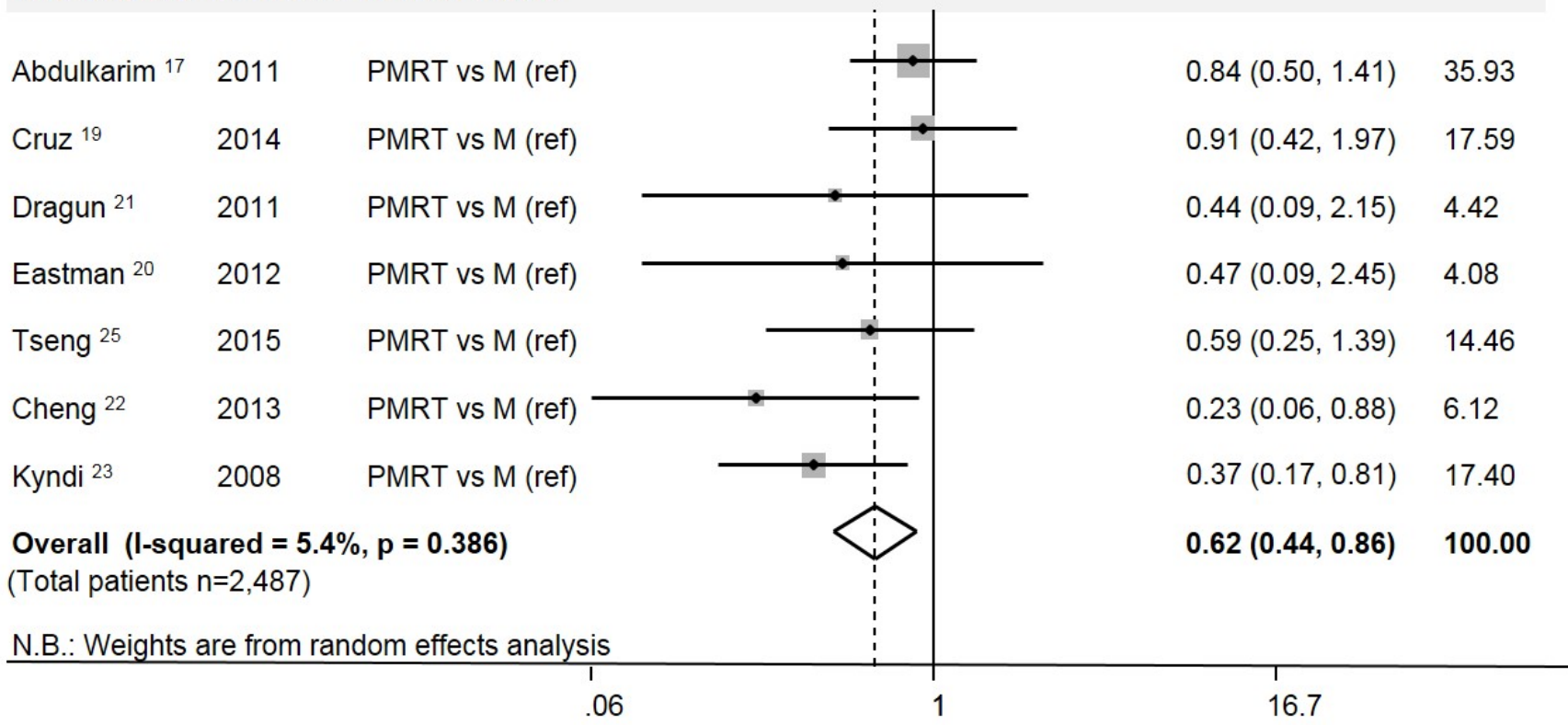


Figure 3:

Study (ref) Year Comparison

HR $(95 \% \mathrm{Cl}) \quad$ Weight (\%)

Distant recurrence: BCT vs. MT

Abdulkarim ${ }^{17} 2011 \quad$ BCT vs M (ref)

Cruz ${ }^{19} 2014 \quad$ BCT vs M (ref)

Dragun $2111 \quad$ BCT vs M (ref)

$2012 \quad$ BCT vs M (ref)

Zumsteg $2013 \quad$ BCT vs M (ref)

Overall (I-squared $=0.0 \%, p=0.656$ )

(Total patients $n=1,615$ )

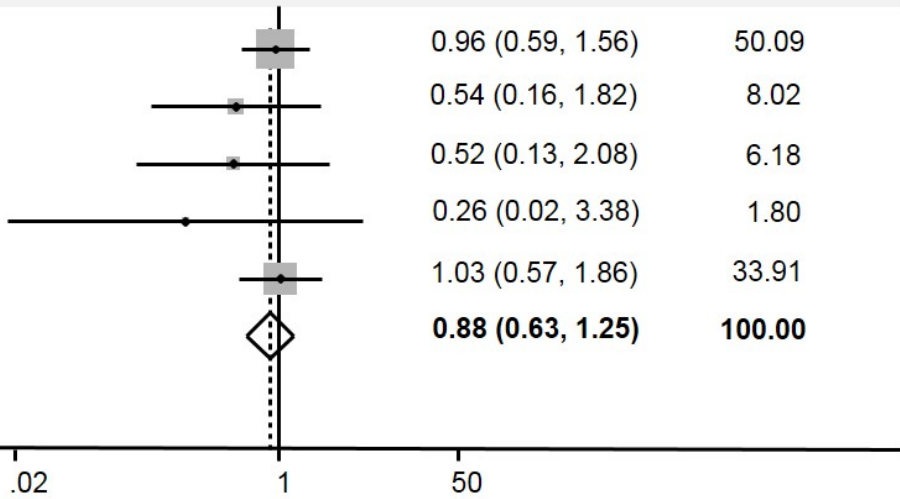

Distant recurrence: PMRT vs. MT

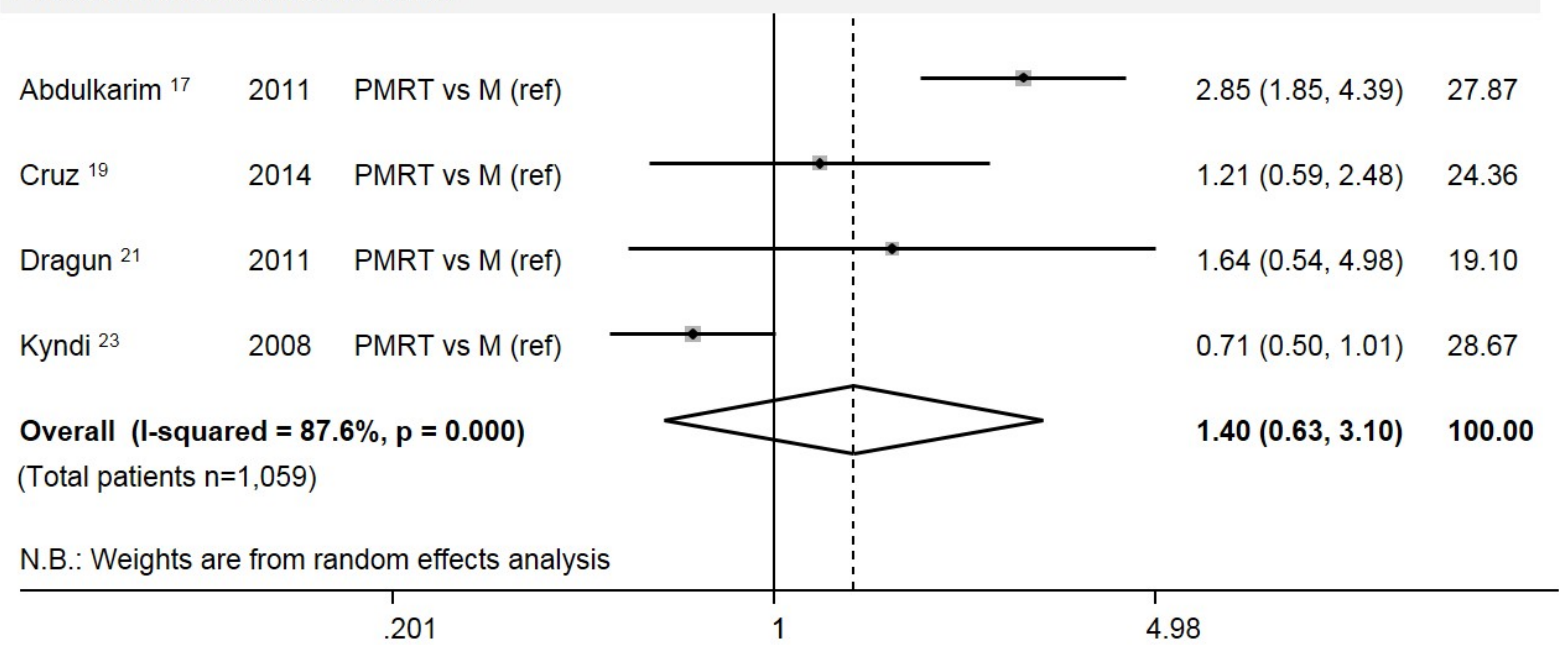


Figure 4:

Study (ref)

Year Comparison

ES $(95 \% \mathrm{Cl}) \quad$ Weight (\%)

Overall Survival: BCT vs MT

$\begin{array}{lll}\text { Abdulkarim }^{17} & 2011 & \text { BCT vs M (ref) } \\ \text { Bhoo-Pathy 18 } & 2015 & \text { BCT vs M (ref) } \\ \text { Cruz }^{19} & 2014 & \text { BCT vs M (ref) } \\ \text { Dragun 21 } & 2011 & \text { BCT vs M (ref) } \\ \text { Steward 24 } & 2014 & \text { BCT vs M (ref) } \\ \text { Zumsteg 29 } & 2013 & \text { BCT vs M (ref) }\end{array}$

Overall (I-squared $=\mathbf{5 0 . 5 \% , p}=\mathbf{0 . 0 7 3}$ )

(Total patients $n=3,184$ )

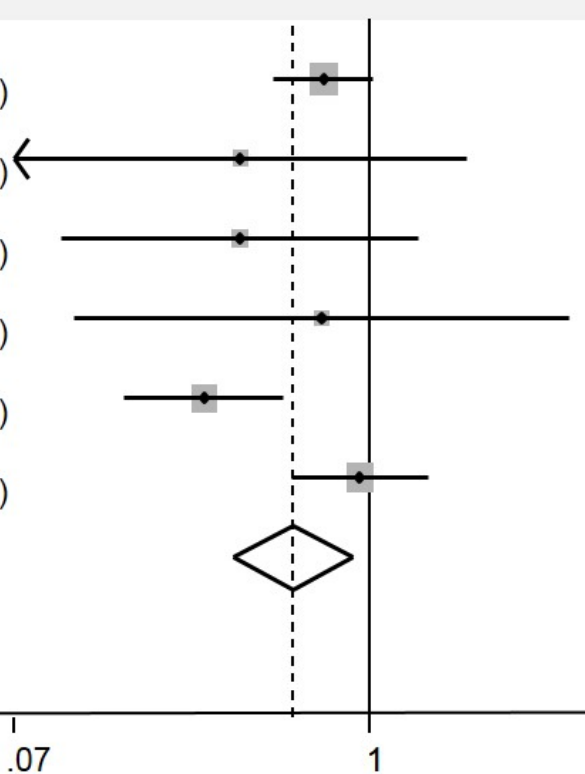

$0.71(0.49,1.03) \quad 31.03$

$0.38(0.07,2.06) \quad 5.90$

$0.38(0.10,1.44) \quad 8.69$

$0.70(0.11,4.45) \quad 5.05$

$0.29(0.16,0.53) \quad 23.19$

$0.93(0.56,1.54) \quad 26.14$

$0.56(0.36,0.88) \quad 100.00$

\section{Overall Survival: PMRT vs MT}

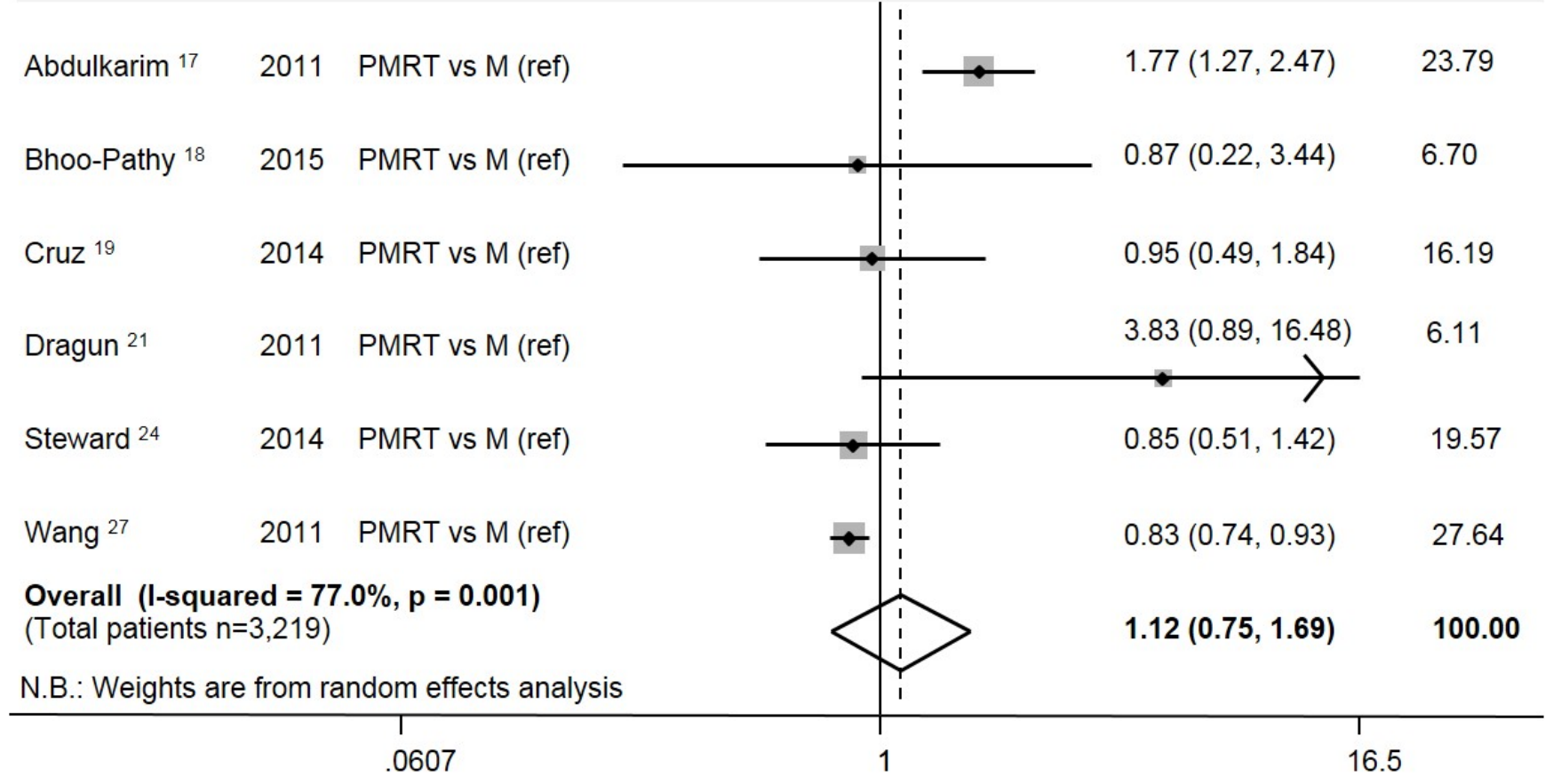


Figure 5:

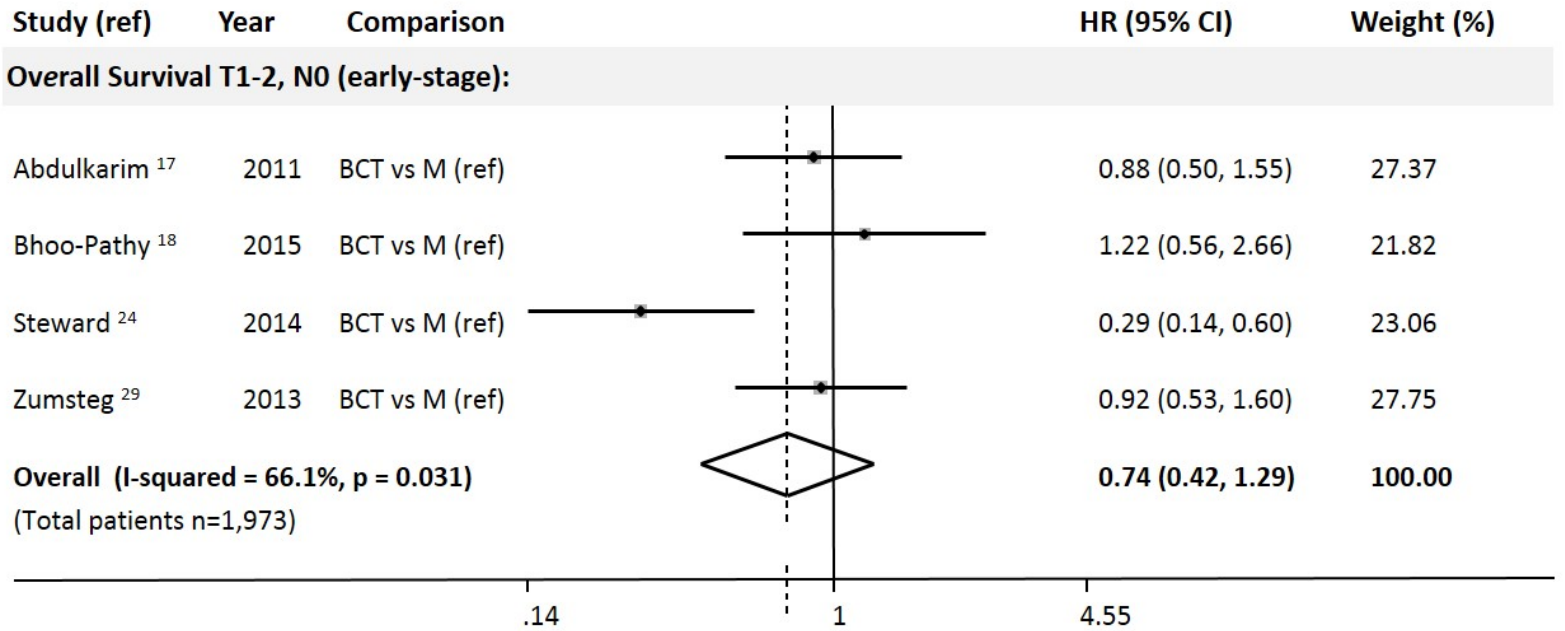

Overall Survival T3-4, N2-3 (late-stage):

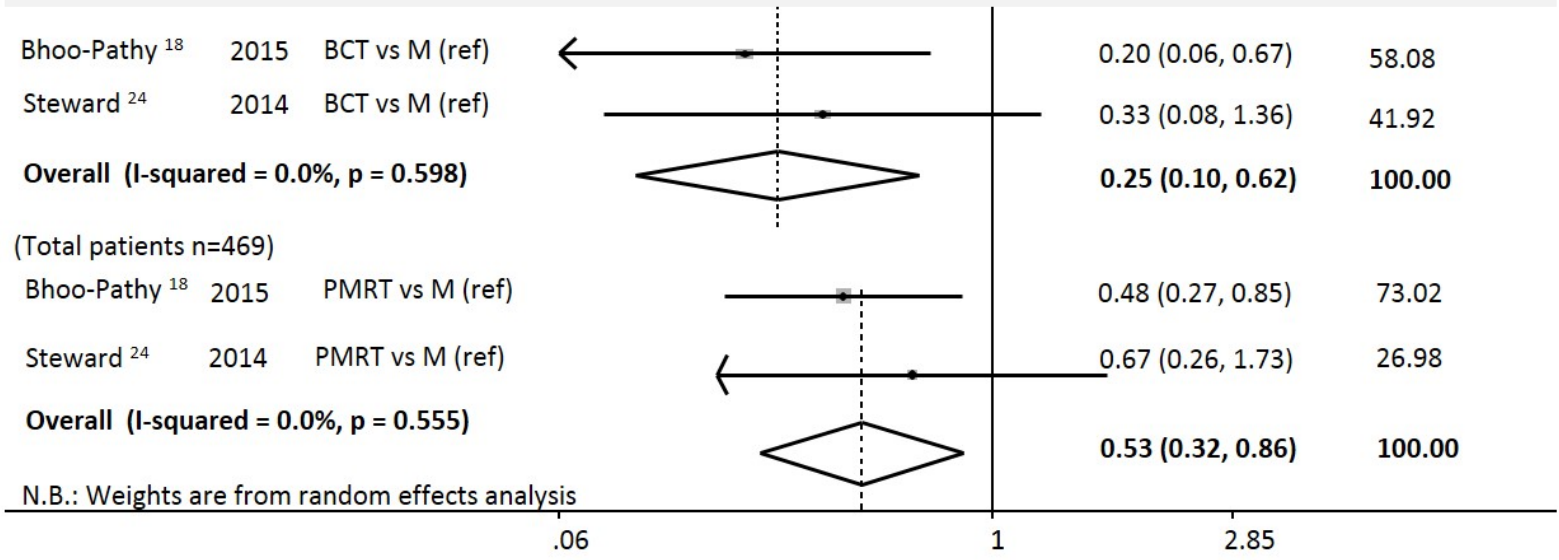


Figure 6:

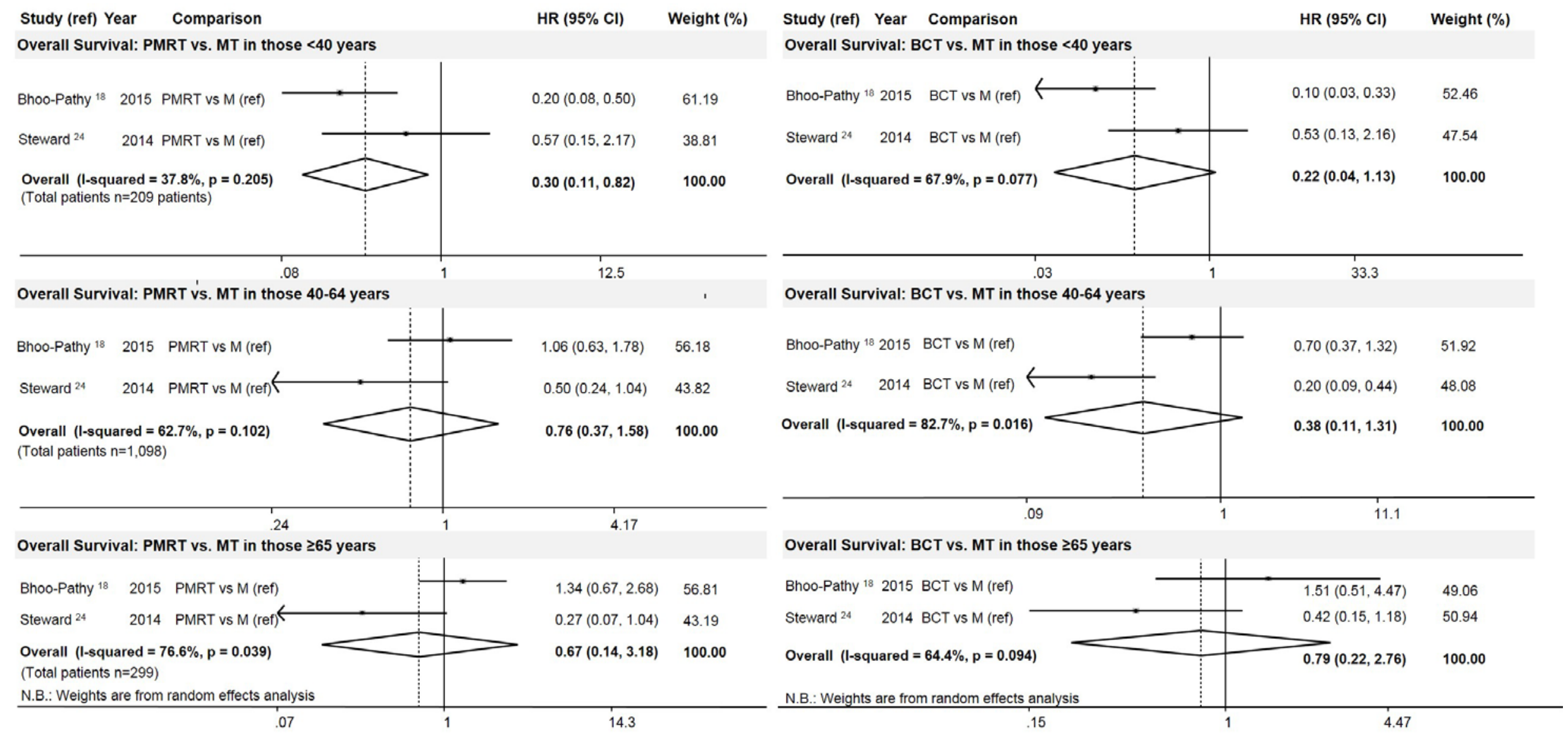


